\title{
An Integrated Approach to Capacity Development in Forestry and Climate Change in West Africa
}

\author{
Kalame Fobissie ${ }^{1,2,3}$, Daniel Etongo ${ }^{1,4}$ \& Markku Kanninen ${ }^{1}$ \\ ${ }^{1}$ Viikki Tropical Resources Institute (VITRI), Department of Forest Sciences, University of Helsinki, Helsinki, \\ Finland \\ ${ }^{2}$ FOKABS Inc. Ottawa, Canada \\ ${ }^{3}$ University of Ottawa, School of International Development and Global Studies (SIDGS), Ottawa, Canada \\ ${ }^{4}$ National Institute for Regional and Spatial Analysis (NIRSA), Maynooth University, Maynooth, Ireland \\ Correspondence: Daniel Etongo, National Institute for Regional and Spatial Analysis (NIRSA), Maynooth \\ University, Maynooth, Ireland. Tel: 35-3-1708-6178. E-mail: Daniel.Etongo@nuim.ie
}

Received: July 24, 2017 Accepted: September 5,2017 Online Published: September 12, 2017

doi:10.5539/jsd.v10n5p35 URL: https://doi.org/10.5539/jsd.v10n5p35

\begin{abstract}
The BIODEV capacity development programme (BCDP) uses forestry, agroforestry and trees to derive a broad range of development and environmental outcomes (high-value biocarbon) while strengthening the capacities of local and national institutions to be able to sustain the benefits. The BCDP conducted 40 long and short-term training activities in Burkina Faso, Guinea, Mali and Sierra Leone across the following categories: (i) Short-term in-country trainings and regional training e.g. support to UNFCCC negotiators running from 2-4 and 6-8 days and implemented using the Harvard Case and the Socratic Learning Methods; (ii) Short-term training abroad for three weeks on Managing Sustainable Forest Landscapes, and (iii) Long-term training abroad e.g. PhD study on forest governance and climate change. The success of BCDP is largely influenced by (i) the effectiveness of coordination and planning amongst trainers; (ii) the content, format, depth, focus and duration of the training vis-a-vis the needs of the trainees; and (iii) the strengthening of existing local and national decision making and implementation platforms for up-scaling high value biocarbon development approaches.
\end{abstract}

Keywords: actors, agroforestry, forestry, adaptation, REDD+, trainings

\section{Introduction}

Support for capacity building and the need to reinforce institutional, human and financial capacities of developing nations has been an area of emphasis since the Rio Earth Summit on environment and development (UNCED, 1992). Technology transfer and financial support are becoming crucial for capacity strengthening especially for developing countries due to their vulnerability that poses a challenge to cope with climate change and to adapt to its effects. Several initiatives and training portfolio have been developed by different institutions with the objective of improving and strengthening capacities in developing countries to implement nationally appropriate actions towards sustainable forest management, climate change adaptation and mitigation (Buyck, 1991, World Bank, 1994, IISD, 2012). The climate change capacity development (C3D) project is one of such initiatives that was designed especially for developing countries based on the recommendations of the conference of parties in Marrakech, Morocco (UNFCCC, 2001). The aim was to strengthen the participation of developing countries in the United Nations Framework Convention on Climate Change (UNFCCC) by fostering human and institutional capacities.

Therefore, capacity building is an approach and/or a process to achieve an objective or a goal. Capacity building is considered as the ability of actors in a society to put in place viable institutions, effective leadership, financial and material resources and skilled human resources to achieve socio-economic goals. Many capacity building approaches and processes are implemented mainly through three types of support activities, namely: organisational support, organisational development and technical assistance (World Bank, 2006, Farrell, 2007). Organisational support is made up of financial and material support provided to the trainees or their institutions. Organisational development includes activities to build the skills of institutions so that they can better achieve their organisational goal (Tobelem, 1992). For example, support to government agencies in the development of policies. Technical assistance on the other hand represents different kinds of short and long term training activities through seminars, 
workshops and specialized study programs.

In the context of Building Biocarbon and Rural Development in (BIODEV) West Africa, the goal of capacity building is to build new skills or enhance existing skills of diverse actors and institutions and develop their capacity to facilitate wider up-scaling of high value biocarbon development approaches in Burkina Faso, Sierra Leone, Mali and Guinea. High value biocarbon development approach entails the building of biological or natural carbon as well as deriving a broad range of development and environmental outcomes that include both carbon and non-carbon benefits through improved agroforestry interventions, forest management and tree planting activities (ICRAF et al., 2012). This approach to sustainable rural development is critical for climate change and the increasing importance of adaptation and mitigation mechanisms such as "to reduce emissions from deforestation and forest degradation, and foster conservation, sustainable management of forests, and enhancement of forest carbon stocks" (REDD+) in Africa (Fobissie et al., 2014). This paper draws on implemented activities in the BIODEV project in West Africa to demonstrate an integrated approach to capacity building in the context of forestry and climate change.

BIODEV is a four-year (2013-2017) project funded by the Government of Finland and implemented by a consortium composed of the World Agroforestry Centre (ICRAF), Centre for International Forest Research (CIFOR), University of Helsinki (UH), University of Eastern Finland (UEF), alongside national partners in Burkina Faso, Guinea, Mali and Sierra Leone. The broader development goal of BIODEV is to achieve sustainable rural development with long-term livelihood and environmental benefits to rural populations and the global community under conditions of a changing climate (ICRAF et al., 2012).

While it is hoped that this goal can be achieved, it also appears clearly that action towards high biocarbon development pathways in Africa is beset with governance and institutional challenges and constraints at the local, national and international levels. To address these challenges and shortcomings, BIODEV has adopted a three-pronged strategy for maximizing value addition and generating outcomes of significance: first, a diagnostic analyses of key barriers and opportunities to biocarbon development, secondly, collaboration with other existing initiatives, and thirdly, strengthening policies, institutions, and capacities in order to enable replication of its findings in other landscapes. A key output of the last option is improved national capacity in biocarbon related issues in Burkina Faso, Sierra Leone, Mali and Guinea. This paper focuses on the third aspect on capacity building and to do so there is a need to identify jointly with the beneficiaries their needs in terms of capacity development and trainings.

\section{Methods}

To proceed with the capacity development, key stakeholders and beneficiaries were identified with the help of national partners and institutions in the case-study countries. This was followed by conducting a capacity need assessment of beneficiaries and also putting in place a team of trainers and resources persons from different disciplines to elaborate and implement a capacity development programme.

\subsection{Identification of Beneficiaries and Target Groups}

The BIODEV capacity development programme (BCDP) focuses on three categories of beneficiaries that include people from policy-planning, implementing agencies and research organisations. Actors from the policy and planning arena include the national climate focal points, national REDD + coordinator/advisor, staff of ministries and governmental institutions working on climate change, forestry, agriculture, and agroforestry. These actors drive the process of capacity development and are expected to gain knowledge and skills during trainings to further develop the capacity of their institutions and organisations. Implementation actors on the other hand are those that carry out extension services, farming and forestry activities, and diverse natural resource interventions at the landscape and community levels. In between the landscape and national level are research organisations and university departments, faculties and schools of agroforestry, agriculture and forestry that are engaged in understanding adaptation and mitigation policies, actions and the different roles of trees in agricultural/forest landscapes.

\subsection{Assessment of Capacity Development Needs and Trainings}

Capacity development needs were assessed through the organisation of national workshops with representatives from the identified target groups. The main objectives of the workshops were double fold; (i) use of SWOT analytical framework to identify the strength, weaknesses, opportunities and threats that can impact the implementation of activities in the areas of agroforestry, forestry, adaptation to climate change and REDD + and, (ii) assess and prioritize training needs and capacity building within research and training institutions, national policy and planning institutions and extension services and NGOs. The Harvard Case Method (HCM) and Socratic Learning Method (SLM) were adopted during the BCDP. 


\subsubsection{Harvard Case Method (HCM)}

The Harvard Case Method (HCM) also known as the case study method (CSM) is a teaching technique that incorporates the problem-based learning approach and other experiential exercises (Teach \& Govahi, 1993). HCM was introduced in 1910 and its application has gone beyond class room teaching into training programs (Rebeiz, 2011). As such, this method have gained importance over the years and is now widely applied in different fields of research and development including capacity strengthening. The advantage of this method over others is that it takes the participants out of the passive mode and forces them to be energetic participants in a simulated real world environment. Trainers in the case of the BCDP assumed the role of facilitators which is considered instrumental for the effective transfer of knowledge and skills through the collective participation between one group of trainees and another (Romm \& Mahler, 1991). Trainees were allowed to practice, test, confirm, stretch, extend and refute existing concepts on forestry and climate change (adaptation and mitigation) in groups as it would be the case in the real world.

\subsubsection{Socratic Learning Method}

The Socratic Learning Method (SLM) is a constructivist learning approach consisting of four key steps (Fig. 1): eliciting relevant preconceptions, clarifying preconceptions, testing one's own hypotheses or encountered propositions, and deciding whether to accept the hypotheses or propositions (Lam, 2011). The SLM is particularly useful when one has to evaluate a proposition contradictory to one originally held belief, or when one has to generate and evaluate one's own hypothesis in the face of new information. In the BCDP, the trainers asked a set of questions on climate change which enabled the trainees to express their view on the subject. Based on their views, the trainers asked for clarification from the trainees which gave them an opportunity to reformulate their preconceptions into a proposition that is either accepted or rejected (See Fig. 1).

These propositions were later tested by further fact check, critical questions, counter-arguments, counter-examples or check for contradiction among the groups of stakeholders. Based on critical evaluation of their views, trainees were allowed to re-assess their opinion and decide whether to accept or reject their propositions as well as preconceptions/misconceptions. This is because the true goal of the SLM is to help trainees examine their own beliefs that will enable them become independent learners with curiosity and sensitivity toward new information, and gradually develop a mental habit of active inquiry and vigorous thinking.

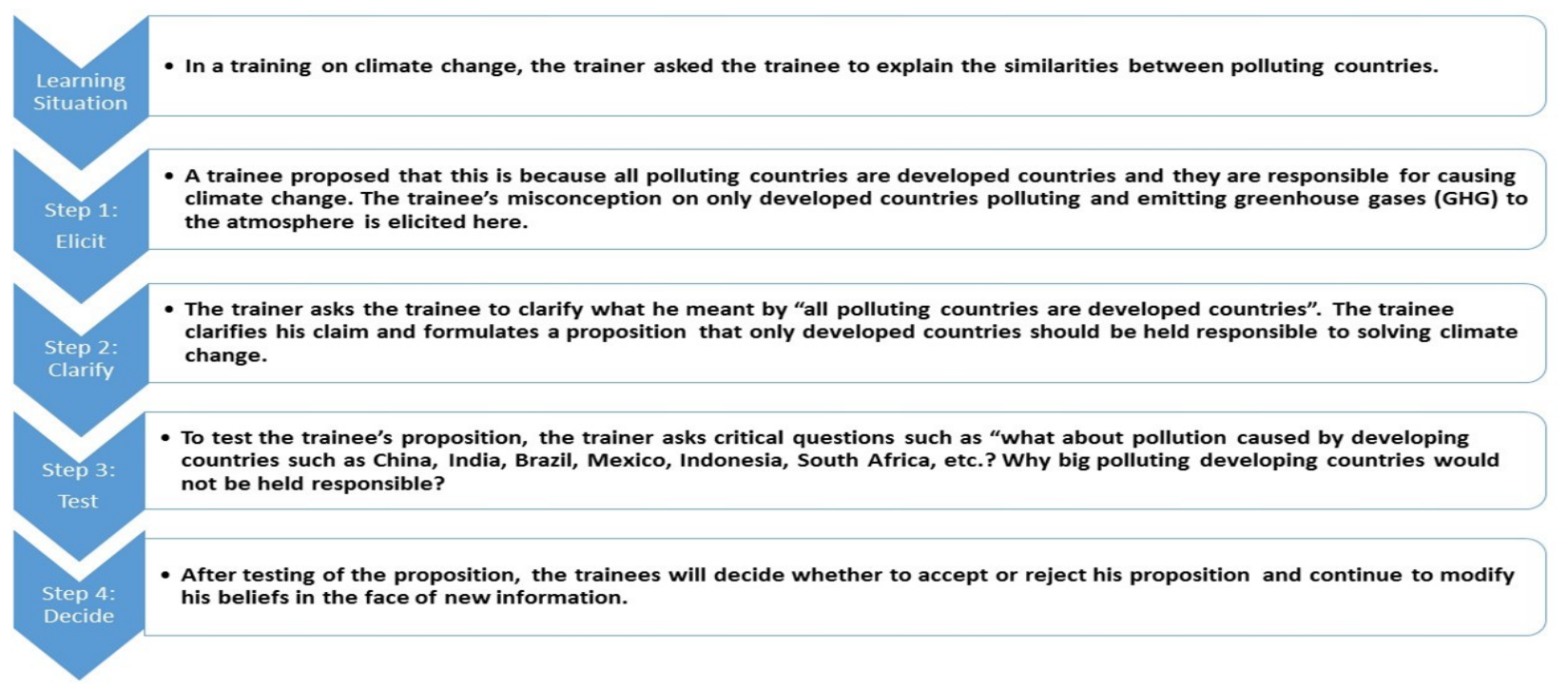

Figure 1. Four stages of the Socratic Learning Method adopted during the trainings

\subsection{Elaboration of Capacity Development Activities}

The identified capacity development needs were used to elaborate a capacity development programme that seeks to meet the needs expressed by different actors. A SWOT analysis on climate change adaptation and mitigation was conducted in Sierra Leone. In addition, the different stakeholders were asked to identify their most important capacity development needs in the following areas; (i) agroforestry/forestry, (ii) climate change 
adaptation, and (iii) REDD + . The implementation of the programme was then conducted mainly through a series of trainings by a team of diverse experts from CIFOR, ICRAF, University of Helsinki as well as local institutions. Each training, depending on the thematic area, focused on a precise target group and was conducted by experts in the said field.

\section{Results}

The following results are presented; (i) SWOT analysis on climate change adaptation and mitigation (REDD+), (ii) priority capacity needs of the three stakeholder groups, and finally (iii) the training activities that were conducted in the case-study countries inclusive of long-term trainings that are ongoing.

\subsection{SWOT Analysis}

The SWOT analysis identifies the strengths, weaknesses, opportunities and threats that need to be considered and addressed in the areas agroforestry and forestry as well as climate change adaptation and mitigation (REDD+). The views of different actors on climate change adaptation and mitigation in Sierra indicated more opportunities compared to other SWOT factors (Table 1). One of the key strength factor is good experience in tree planting that has developed into the 'billion tree campaign' across Sierra Leone. Another strength mentioned by stakeholders is the establishment of protected areas, some of which have become attractive for REDD+ projects - a case in point is the Gola rainforest REDD project located in the south eastern edge of Sierra Leone.

Aside from the strengths that were mentioned, weaknesses such as problem of monitoring and measurement of carbon stocks are confronted with lack of available tools and equipment and also the lack of trained personnels. In addition, the early warning system based in the meteorological department is poorly equipped and therefore exposes the country to uncertain impacts of climate change such as floods, etc. because of low level of awareness. Climate change experts are yet to acquire knowledge and skills in negotiations to enable Sierra Leone to effectively participate and benefit from the Green Climate Fund (GCF). Some of the threats mentioned include soil depletion, deforestation and land degradation and poverty (See Table 1), an indication of low input into agriculture, inappropriate implementation of land management practices considered sustainable, and land grabbing for agribusiness development that pushes poor farmer to occupy marginal lands.

Table 1. A SWOT analysis of climate change adaptation and mitigation (REDD+) in Sierra Leone

\begin{tabular}{clrl}
\hline Strenghts: & Opportunities: \\
\hline$\checkmark$ & Existing research and on climate change; & $\checkmark$ & Explore Least Developed Countries' fund to design \\
$\checkmark$ & Land use planning (Inland valley swamps); & & NAPA and NAP; \\
$\checkmark$ & Introduction of adaptive crops (cassava & $\checkmark$ & Pilot project on sustainable land management \\
& etc.); & $\checkmark$ & NGOs support to use adaptive technologies (rainwater \\
$\checkmark$ & Good experience in tree planting; & & harvesting technologies); \\
$\checkmark$ & Established protected areas. & $\checkmark$ & Estabishment of weather stations; \\
& & $\checkmark$ & Promote alternative livelihood strategies; \\
& $\checkmark$ & National tree planting day; \\
& $\checkmark$ & Establishment of climate change secretariat;
\end{tabular}

\section{Weaknesses:}

$\checkmark \quad$ Low climate change awareness level;

$\checkmark$ Weak institutional capacity;

$\checkmark \quad$ In adequate climate change expert;

$\checkmark$ Absence of carbon mapping

$\checkmark$ Problem of monitoring and measurement of carbon stocks

$\checkmark \quad$ Limited information on carbon markets.

\section{Threats:}

$\checkmark$ Adverse weather conditions;

$\checkmark$ Limited (uncertainty to access) financial resources for international/regional partners;

$\checkmark$ Soil depletion

$\checkmark$ Deforestation and land degradation

$\checkmark$ Poverty. 
However, there are opportunities that could be exploited and further developed in order to improve both adaptation and mitigation strategies to climate change in Sierra Leone and West Africa in general. Least developed countries' fund (GCF) could be exploited to assist in the design of national adaptation programmes of action (NAPA) and national adaptation plan (NAP). Supports from NGOs in rainwater harvesting technologies have been implemented in different parts of the country - an initiative with the potential of improving soil and water conservation on farmlands. The national tree planting day that usually comes up on $5^{\text {th }}$ June each year is organized by the Ministry of Agriculture, Forestry and Food Security (MAFFS), Sierra Leone in collaboration with other ministries and institutions. School pupils and citizens plant a tree each in their community and this is an opportunity that can be exploited to rehabilitate degraded lands through the planting of multipurpose trees while educating the population on the importance of trees for both livelihoods and environmental protection.

\subsection{Priority Capacity Development Needs}

Capacity development needs in the agroforestry/Forestry sector is important for research and university institutions and also for extension services and NGOs. On the other hand, this aspect was not considered important by stakeholders representing national policy and planning institutions, rather their focus was on the development of legislations and policies for agroforestry (Table 2). Different institutions/actors are likely to have diverse needs in terms of capacity development. For example, the implementing agencies such as extension services and NGOs requires knowledge and skills for adaptation and forestry interventions because most of the experts from these sectors work directly with farmers.

The request for training courses on climate management and climate change implies that training materials and equipment together with trained personnel are needed in most universities and research institutions. The training of local expertise is invaluable for climate change adaptation at the local level especially to provide support to farmers on issues related to land rehabilitation and management. Finally, in terms of REDD+, actors from the national policy and planning institutions are still to understand the concept and what is or is not a REDD+ project whereas actors from research and university institutions and extension services and NGOs are in need of different forms of training programs and awareness raising (Table 2).

Table 2. Most important capacity development needs in Sierra Leone identified by different actors

\begin{tabular}{|c|c|c|c|c|c|}
\hline \multicolumn{6}{|c|}{ National Policy and Planning Institutions } \\
\hline & Agroforestry/Forestry & & Adaptation & & REDD+ \\
\hline \multirow[t]{2}{*}{$\checkmark$} & Elaboration of agroforestry & $\checkmark$ & Elaboration of adaptation & $\checkmark$ & Elaboration of REDD + projects \\
\hline & projects & & projects & $\checkmark$ & Support the formation of a National \\
\hline$\checkmark$ & Basics agroforestry concepts & $\checkmark$ & Understanding climate change & & REDD + committee and the \\
\hline \multirow[t]{4}{*}{$\checkmark$} & Support the development of & & and adaptation science & & development of REDD + \\
\hline & legislations and policies for & $\checkmark$ & Support the formation of a & & legislations/policies \\
\hline & agroforestry & & National Adaption committee & $\checkmark$ & Understanding REDD + concept \\
\hline & & & and policies & & and issues \\
\hline \multicolumn{6}{|c|}{ Research and University Institutions } \\
\hline & Agroforestry/Forestry & & Adaptation & & $R E D D+$ \\
\hline \multirow[t]{2}{*}{$\checkmark$} & How to network with & $\checkmark$ & Take courses on land & $\checkmark$ & Training of lecturers and \\
\hline & international institutions & & management and climate & & researchers on REDD+ \\
\hline \multirow[t]{3}{*}{$\checkmark$} & Training/research in & & change & $\checkmark$ & Introduction of short and long term \\
\hline & Agroforestry, forestry and & $\checkmark$ & Mobilization of funds & & climate change courses in \\
\hline & climate change & $\checkmark$ & Identification and & & universities. \\
\hline \multirow[t]{2}{*}{$\checkmark$} & Writing research proposals and & & diversification of adaptive & & \\
\hline & scientific publications & & technologies & & \\
\hline
\end{tabular}




\begin{tabular}{|c|c|c|c|c|c|}
\hline \multicolumn{6}{|c|}{ Extension Services and NGOs } \\
\hline & Agroforestry/Forestry & & Adaptation & & REDD+ \\
\hline$\checkmark$ & Staff capacity-building & $\checkmark$ & Training of local expertise & $\checkmark$ & Training in MRV, finance and \\
\hline$\checkmark$ & Mobilization of funding & $\checkmark$ & Rehabilitation of degraded & & carbon markets \\
\hline \multirow[t]{3}{*}{$\checkmark$} & Community alternative & & areas & $\checkmark$ & Training of Trainers for \\
\hline & livelihoods strategies & $\checkmark$ & Awareness raising and & & NGOs/CSOs \\
\hline & & & advocacy & $\checkmark$ & Advocacy \& awareness raising \\
\hline
\end{tabular}

\subsection{Training Activities}

In order to implement capacity development activities, technical assistance was provided mainly through 5 types of trainings composed of 40 different training activities (Table 3). For the long-term training based on PhD studies, one of the trainees have completed while three others are ongoing at Helsinki University, Finland. This category of training offers participants the opportunity to acquired knowledge and skills in forestry and climate change. Six participants from Mali, Burkina Faso and Sierra Leone took part in the Helsinki Summer School in 2015 entitled "Managing Sustainable Forest Landscapes". This is an intensive professional training course in which both the principles and practices of forestry and climate change adaptation and mitigation are thought. Short-term in-country trainings were conducted in the case-study countries at two levels (Table 3) while a policy training and negotiations process for UNFCCC was conducted at the regional level in West Africa. The following trainings were conducted: (1) Trainings on the outcome of UNFCCC COP21 and COP22 across five locations in Burkina Faso (Ouagadougou, Bobo Dioulasso, Ouhigouya, Kaya and Koudougou) on 30 November 2016 and 1-6 December 2016 with a total of 360 participants, (2) Training on climate change science, adaptation and mitigation between 16-21 February 2015 at Ouagadougou, Burkina Faso with 23 participants from Burkina Faso and 8 from Mali, (3) Training on the elaboration and evaluation of climate change projects took place between 7-11 April 2015 in Ouagadougou, Burkina Faso with 30 participants from Burkina Faso and 6 from Mali, and (4) Outcomes and implications of the Paris climate change conference with 51 participants on 21 April 2016, Freetown, Sierra Leone. The participants in all the above four trainings came from the government, universities, non-governmental organizations (NGOs), research institutions and private sectors in Burkina Faso, Mali and Sierra Leone.

Table 3. Different training activities to be conducted in Sierra Leone and other West African countries

\begin{tabular}{|c|c|c|}
\hline Type of Training & Duration & Examples \\
\hline Long term abroad & $1-3$ years & PhD studies on climate change governance or carbon measurements \\
\hline Short term abroad & $\begin{array}{l}2-4 \\
\text { weeks }\end{array}$ & $\begin{array}{l}\text { Summer school course or intensive professional training on gender, forestry } \\
\text { and climate change }\end{array}$ \\
\hline $\begin{array}{l}\text { Short term } \\
\text { in-country I }\end{array}$ & $2-4$ days & $\begin{array}{l}\text { Implementation of extension tools and materials, forest management } \\
\text { planning }\end{array}$ \\
\hline $\begin{array}{l}\text { Short term } \\
\text { in-country II }\end{array}$ & 5-7 days & $\begin{array}{l}\text { Development of and international standards for evaluating adaptation and } \\
\text { REDD + projects }\end{array}$ \\
\hline $\begin{array}{l}\text { West Africa } \\
\text { Regional }\end{array}$ & 2-7 days & Preparations for UNFCCC negotiations \\
\hline
\end{tabular}

\section{Discussion}

SWOT analysis: The SWOT analysis enabled participants to identify their strength, weaknesses, opportunities and threats linked to agroforestry, forestry, adaptation and REDD + . Generally, it was revealed during the regional workshops in West Africa that issues and aspects of adaptation and REDD are not well understood by many of the participants especially some technicalities at the international level. This is explained by the fact that adaptation and REDD+ are fairly new concepts and processes for many participants who were rather more familiar with factors linked to their organisations and country. In addition, making a distinction between ex ante (anticipatory) or ex post 
(reactive) adaptation, and planned and autonomous adaptation still remains a challenge among different actors - a view that is supported by Prowse and Snilstveit (2010). Furthermore, payment for ecosystem services (PES), have introduced not just a new terminology but the importance of other co-benefits aside from carbon which is both complicated and difficult to understand as to what qualifies for a REDD+ project (Angelsen et al., 2009).

Understanding adaptation as a process is still relatively new to many actors in the case-study countries. This is because the high dependence on resources such as fisheries, forestry, agriculture and livestock that are sensitive to the impacts of climate change often result into uncertainties that are difficult to handle (Matsaert, 2002). The mismatch between adaptation policies and strategies and actions/interventions further open new challenges of mal-adaptation. Even when appropriate policies and interventions do exist, an enabling environment is required for effective implementation. Recognizing the inadequacy of existing learning tools with a specific focus on poverty and complex livelihood-vulnerability risks continue to dilute the impacts of adaptation interventions (Tschakert \& Dietrich, 2010). Therefore, the selection and design of climate change interventions (mitigation and adaptation) should be based on evidence of what works, what doesn't, under what circumstances and at what cost (Adger et al., 2003, Prowse \& Snilstveit, 2010).

Aside from understanding the adaptation process among actors, the available information on climate change is poorly understood. The consequences of this is the design and implementation of climate interventions that do not align with people's needs and thereby increasing the vulnerability of communities to the impacts of climate change. However, in order to address these risks, climate change information needs to be better understood by decision makers and appropriately integrated into national and sectoral policies and plans such as NAPA and NAP (ASSAR, 2015a, Fobissie et al., 2016). This is because greater integration of climate information would help to support more responsive mechanisms, prioritization of financial resources, and strengthening of institutional capacities to effectively implement adaptation interventions (ASSAR, 2015b). The integrated approach of the BCDP can only become effective if institutions, government ministries and the private sector that are involved in natural resources management in one way or the other jointly collaborate in addressing climate risks while promoting joint climate finance mechanisms.

Cross-cutting themes for capacity building: Common training and capacity building needs and trends identified by participants cut across two focal areas of intervention and include amongst others, (i) the elaboration and development of projects in order to mobilize financial resources, and (ii) the training of trainers on the different thematic areas of agroforestry, forestry, climate change adaptation and REDD+. Capacity building especially on project writing and advocacy is important to access existing funding on climate change. Though these funding instruments do exist, the access rate especially for African countries is very low. A study in Africa indicated that there is need to capture more of the funds of the avoided deforestation in order to address both mitigation and adaptation (Mbow et al., 2012). The training of trainers is considered by most national actors to be crucial in building a critical mass for long term actions. Capacity building has been identified as the missing link in African development (Jaycox, 1993) because the use of tools in assessing climate change adaptation and local livelihoods is yet to be effective due to a lack and in some cases shortage of trained personnel (IISD, 2012).

Training focus: The identified priorities shows that the training needs are generally similar at the regional and national levels on adaptation and REDD+ while at the subnational and local levels, the needs become diverse on agroforestry and forestry field interventions. This suggest that the trainings on climate change adaptation and mitigation (REDD+) could in many cases use almost similar adjustable training modules while training modules on agroforestry and forestry shall probably be location specific. This is because the latter is more complex ecologically and economically and should be tailored-made to suit local realities - a finding that is similar to an earlier study conducted in southern Africa (Govere, 1997).

Training formats and duration: Participants considered face-to-face training to be the most practical way for capacity building due to poor energy and information technology infrastructures. Innovative training mechanisms and tools like webinars, skype conferences and online courses are not possible. Participants also considered two training durations - short and long term, to be the most effective ways to build capacities of younger and older generations respectively. Two knowledge gaps were identified; at the top and the bottom. At the top e.g. the universities, teachers lack the qualification and skills to train the students while at the bottom, the extension worker lack the technical skills and knowledge to advice farmers. Technical and university education requires urgent attention that might require restructuring of Africa's natural resources education into a more problem-based approach - a view corroborated by another study in Africa (Temu \& Kiyiapi, 2008). Training of government officials, decision makers and permanent staff may be easily realized through short term targeted workshops, diploma/intensive courses, conference participation, etc. Long term training on the other hand should focus for example on training Masters and $\mathrm{PhD}$ students. The training can either take place in universities at home or abroad 
depending on the availability of the required training and financial support.

\section{Conclusion}

This paper uses the BIODEV capacity building approach to show that the identification, engagement and consultation of beneficiaries within a given capacity development and training process provides the opportunity to design and implement training activities that respond to the needs of the beneficiaries. Through a capacity need assessment process, key stakeholders and beneficiaries are able to identify and prioritize their trainings and capacity development needs. Hence, the entire capacity building approach and content is defined by key stakeholder and beneficiaries and not the project or funder of a given project. At this stage, and given that the capacity building process is still under implementation, it may be premature to draw conclusions and provide recommendations on the longer term impact which will only be assessed after the completion of the training process.

\section{Acknowledgements}

The study and workshop were financed by the BIODEV project funded by the Ministry of Foreign Affairs of Finland. BIODEV project staff especially from ICRAF provided organizational, technical, logistics and facilitation supports. This paper was made possible by the discussions and contributions of all the workshop participants from Burkina Faso, Mali, Sierra Leone and Guinea. The views expressed in this information product are those of the authors and do not necessarily reflect the views or policies of FAO, BIODEV partner institutions, and the Ministry of Foreign Affairs of Finland.

\section{References}

Adger, W. N., Huq, S., Brown, K., Conway, D., \& Hulme, M. (2003). Adaptation to climate change in developing world. Progress in Development Studies, 3(3), 179-195. https://doi.org/10.1191/1464993403ps060oa

Angelsen, A., Brockhaus, M., Kanninen, M., Sills, E., Sunderlin, W. D., \& Wertz-Kanounnikoff, S. (Eds.) (2009). Realising REDD+: National Strategy and Policy Options. CIFOR, Bogor, Indonesia.

ASSAR. (2015a). Planning for climate change in the dryland areas of West Africa. Adaptation at Scale in Semi-Arid Regions (ASSAR). Information Brief \# 1. Retrieved February 14, 2017, from http://www.ASSARadapt.org

ASSAR. (2015b). How can climate change adaptation in the semi-arid regions of West Africa be more effective and widespread? Evidence from Ghana and Mali. Adaptation at Scale in Semi-Arid Regions (ASSAR). Information Brief \# 2. Retrieved February 14, 2017, from http://www.ASSARadapt.org

Buyck, B. (1991). The Bank's use of technical assistance for institutional development. Policy Research and External Affairs Working Paper No. 578. World Bank, Washington DC, USA.

Farrell, C. (2007). The Canadian Hunger Foundation (CHF) Capacity Building Approach. Ottawa, Canada.

Fobissie, K., Alemagi, D., \& Minang, P. A. (2014). REDD+ Policy Approaches in the Congo Basin: A Comparative Analysis of Cameroon and the Democratic Republic of Congo (DRC). Forests, 5, 2400-2424. https://doi.org/10.3390/f5102400

Fobissie, K., Kanninen, M., \& Etongo, D. (2016). A systematic approach to strengthening capacities on climate change and natural resource management in West Africa. VITRI Brief Number 2.

Govere, E. M. (1997). Research, extension and training needs for agroforestry development in Southern Africa. The Southern African Forestry Journal, 180 (1), 49-53. https://doi.org/10.1080/10295925.1997.9631168

ICRAF, CIFOR, Helsinki University, University of Eastern Finland. (2012). Building biocarbon and rural development in West Africa (BIODEV), Programme document. World Agroforestry Center (ICRAF), Nairobi, Kenya.

IISD. (2012). CRiSTAL User's Manual Version 5. Community-based Screening Tool - Adaptation and Livelihoods. International Institute for Sustainable Development, Manitoba, Canada.

Jaycox, E. (1993). Capacity Building: The Mising Link in African Development. Adress to African-American Institute Conference, Reston, Virginia, May 20, 1993.

Lam, F. (2011). The Socratic method as an approach to learning and its benefits. Senior Honor Thesis, Carnegie Mellon University, USA.

Matsaert, H. (2002). Institutional analysis in natural resources research: Socio-economic methodologies for Natural Resources Research. Best Practice Guidelines. Natural Resources Institute, Chatham, UK. 
Mbow, C., Skole, D., Dieng, M., Justice, C., Kwesha, D., Mane, L. ... Virji, H. (2012). Challenges and prospects for REDD+ in Africa: Desk Review of REDD+ Implementation in Africa. GLP Report No. 5. GLP-IPO, Copenhagen.

Prowse, M., \& Snilstveit, B. (2010). Impact evaluation and interventions to address climate change: A scoping study. International Initiative for Impact Evaluation, Working Paper 7. New Delhi, India. https://doi.org/10.1080/19439341003786729

Rebeiz, K. S. (2011). An Insider Perspective on Implementing the Harvard Case Study Method in Business Teaching. US-China Education Review, 5, 591-601.

Romm, T., \& Mahler, S. (1991). The case study challenge: A new approach to an old method. Management Education and Development, 22(4), 292-301. https://doi.org/10.1177/135050769102200404

Teach, R., \& Govahi, G. (1993). The role of classroom techniques in teaching management skills. Simulation and Gamming, 24(4), 429-445. https://doi.org/10.1177/1046878193244002

Temu, A. B., \& Kiyiapi, J. (2008). Restructuring Africa's Forestry Education, in New Perspective in Forestry Education. North Karelian: IPFE Secretariat, University of Joensuu, Finland. Retrieved December 20, 2016, from http://www.worldagroforestry.org/downloads/Publications/PDFS/BC08172.pdf

Tobelem, A. (1992). Institutional capacity analysis and development system: Operational manual. LATPS Occasional Paper Series No. 9, July 1992. Retrived November 6, 2016, from http://documents.worldbank.org/curated/en/860851468091484897/pdf/multi-page.pdf

Tschakert, P., \& Dietrich, K. A. (2010). Anticipatory learning for climate change adaptation and resilience. Ecology and Society, 15(2), 11. https://doi.org/10.5751/ES-03335-150211

UNFCCC. (2011). The Marrakesh accords. Retrieved March 22, 2017, from http://unfccc.int/resource/docs/cop7/13a01.pdf

United Nations Conference on Environment \& Development. (1992). Rio de Janerio, June 3-14, 1992. AGENDA 21. Retrieved January 28, 2017, from https://sustainabledevelopment.un.org/content/documents/Agenda21.pdf

World Bank. (1994). Capacity building in World Bank-supported forestry projects in sub-Saharan Africa. AFTES Working Paper No. 6. Natural Resource Management, Environmentally Sustainable Development Division. Africa Technical Department. The World Bank, Washington DC, USA.

World Bank. (2006). Capacity development resource center - Perspectives and definitions. The World Bank, Washington DC, USA.

\section{Copyrights}

Copyright for this article is retained by the author(s), with first publication rights granted to the journal.

This is an open-access article distributed under the terms and conditions of the Creative Commons Attribution license (http://creativecommons.org/licenses/by/4.0/). 